\title{
DETERMINANTS OF TRANSPORT COMPANY VALUE AND THE SELECTION OF VALUATION METHODS \\ Eva Adámiková ${ }^{1}$, Tatiana Čorejová ${ }^{2}$, Lenka Môcová ${ }^{3}$
}

\begin{abstract}
The development of a company significantly influences its final value. The value of a transport company can be determined for various legal acts, which also influence the selection of valuation methods. The view of the transport company may differ, depending on whether it is seen by investors or the company owners. Methods of evaluating a transport company, but also of all companies in expert practice, usually follow methodological procedures outlined in the legal standards. These methods are based on basic principles, namely the asset principle, the yield principle, the combined principle, and the market principle. These principles also include other methods of determining the company's value. Each method has its own specifics, a modification of only one model parameter changes the entire company value. The aim of this paper is to analyze the input data and their impact on the value of the transport company from the perspective of various methods. The paper shows the impact of the change in the rate of capitalization and $g$ - the sustainable growth rate and the significant impact of the continuing value on the general value of the company.
\end{abstract}

JEL Classification Numbers: M41, G32, DOI: 10.12955/cbup.v7.1334

Keywords: transport company value, company assets, asset method, yield method

\section{Introduction}

The value of a transport company can be determined for different legal acts that affect its outcome. A particular view of a company can be taken by owners who may want to establish the value of their business, for example, for the purpose of selling, non-monetary deposit, liquidation of the company, or for determining the value of shares in public limited companies, or the value of the business share, for example in settling the undivided co-ownership of spouses and redemption of shares at divorce. Investors who want to invest in a particular company strive to establish the value of the company in terms of their investment and its return in the future. Yet another perspective is taken by the accountant who applies the accounting data in the calculation of its book value.

Determining a company's book value is a simple, but not a very accurate method. This method is based on calculating the book value of the company's assets that are reported on the asset side of the financial statement of a company. From this value the amount of borrowed resources, which is reported in the financial statement on the liabilities side, is then deducted, i.e. the sum of reserves, long-term and shortterm liabilities, bank loans, short-term financial assistance and accruals (Jankalova, 2013; Kislingerova, 2001; Majduchova et al., 2018). The result is the difference representing the company's equity, which is, in essence, the net book value of the company. For many legal acts, the book value is inadequate. It is necessary to estimate the market value by experts.

For valuation practice, the general value of a company or its parts is defined in Decree 492/2004 Coll. on the determination of the general value of the property, the property for the purposes of the Decree being understood according to $\S 2$ subsection (a) as the assets of the company as a whole, part of the company, component of the company's assets or assets other than the company assets.

In determining the value of a company, it is important that each of the valuation methods takes into account the key factors of the issue. The value of the objectified asset must consider the acquisition cost of the asset concerned, its degree of depreciation, the development of the market prices of the relevant asset components from the time they are acquired to the time of their valuation. Moreover, it must include the cost associated with the establishment, operation and management of a company and its financial structure, i.e., the share of owned and borrowed capital that covers the assets of the company, as well as the deadlines related to the fulfillment of its obligations (Dong, 2018). An important factor in determining the value of a company by the yield principle is the consideration of its future yield, a welldesigned business plan that is related to past business development, especially when the company is valued for an unlimited lifetime (Gu et al., 2017; Na et al., 2017; Xiao, 2017).

\footnotetext{
${ }^{1}$ Deparment of Communications, The Faculty of Operation and Economics of Transport and Communications, University of Žilina, Slovak Republic, eva.adamikova@fpedas.uniza.sk

${ }^{2}$ Deparment of Communications, The Faculty of Operation and Economics of Transport and Communications, University of Žilina, Slovak Republic, tatiana.corejova@fpedas.uniza.sk

${ }^{3}$ Institute of Lifelong Learning, University of Zilina, Slovak Republic lenka.mocova123@gmail.com
} 
A key factor in selecting a method, as well as a factor influencing the value of a company, is its life cycle, as it is appropriate to use a different valuation method at each stage of the life cycle or the rate of intangible assets in company assets (Huang, 2017). The amount and quality of information available to the expert also play a significant role.

\section{Methods for determining the value of assets}

A general value in the sense of Decree 492/2004 Coll. shall be understood in $\S 2$ subsection (g) as the resulting objectifiable value of an asset, which is the expert assessment of the most likely value of the valued asset on the valuation date at the given time and location. The asset shall reach the value on the market under conditions of free competition, fair trade between a willing buyer and a willing seller in an arm's length transaction, after proper marketing and with the parties having each acted knowledgeably, prudently and without compulsion, under the presumption that the price was not influenced by an inadequate motive. It usually includes value-added tax.

The value of a transport company is influenced by a large set of factors that experts should take into account in the process of objectification and include into their calculations. These are internal and external factors as well as the purpose for which the value is determined. The purpose of the valuation may stem from internal or external needs. The needs can specifically include the internal needs of the valuated company in connection with the purchase and sale of the company, its division or the division of its parts (e.g. due to mergers, bankruptcy, new partner, etc.); or for external needs, in connection with a loan application, property insurance, litigation, criminal proceedings, tax purposes, etc. The use of a particular method must be justified in the expert testimony. The general value of an enterprise is determined by a legal entity, namely an expert body or an expert organization.

In Decree 492/2004 Coll. on the determination of the value of the asset, several methods are defined to determine the general value of a company. These methods are based on certain fundamental principles such as asset principle, yield principle, combined and market principle. Most commonly used methods are based on the asset and yield principle or their combination.

Asset principle - The value of a company is calculated from the value of the individual components of the company's assets from which the value of the obligations is deducted. In Decree 492/2004 Coll., the valuation of the general value of assets is mainly attributable to the asset and liquidation method.

"The company's asset valuation principle represents a static view of the enterprise as a whole while respecting the principle of conservation of substance. It requires the cooperation of experts from technical and economic fields, precise organization of the work, provision of documents, property inspections, consultations with the contracting authority, as well as the use of all the skills and expertise of the experts." (Sedlakova, 2012)

The general value of the company and its parts by the asset method is determined as follows:

$$
V S H=\sum_{i=1}^{n} V S H_{Z M_{i}}-V S H_{C Z}
$$

where:

$\mathrm{VSH}_{\mathrm{ZMi}}$ - the general value of the company and its the parts determined by the asset method $[€]$,

$\sum^{n} \quad$ the sum of the general values of all the parts of the assets that are the subject of $\sum V S H_{Z M_{i}}{ }^{-}$valuation [€],

$\mathrm{VSH}_{\mathrm{CZ}} \quad$ - the general value of borrowed resources $[€]$.

Besides the company's own value, the method also provides information on the value of specific components of the assets and liabilities individually. This is necessary if the company will apply the expert testimony in accounting. Also, the method is used when the entrepreneur does not have a clear business intention, or if the business plan does not relate to the historical development of the company or shows a loss. The disadvantage of this method is its time-consuming and labor-intensive nature as 
well as financial costs of its implementation. The asset method does not take into account the yield potential of the company.

Yield principle - In this case, the value of the company is determined on the basis of the withdrawable resources that the company will generate in the future. In the Decree, the yield principle is applied in the yield method.

The yield method is defined in detail in Decree no. 492/2004 Coll. on the determination of the general value of the assets. This method can be used with companies with an unlimited or limited lifetime. Most often, the calculation is applied to companies with an unlimited lifetime.

For our purposes, we will specify a basic relationship for prosperous companies, with unlimited lifetime (the so-called going concern principle):

where

$$
V S H_{P}=H_{O Z}+H_{P} \quad[€],
$$

$V S H_{P}$ - the general company value determined by the yield method [€],

$H_{O Z}$ - the value of withdrawable resources during the evaluated period [€],

$H_{P} \quad$ - continuing value $[€]$.

After adding the basic value of the withdrawable resource and the continuing value, the general value determined by the yield method was calculated according to the following relationship:

$$
V S H_{P}=\sum_{t=1}^{n} \frac{o Z_{t}}{(1+\mathrm{i})^{\mathrm{t}}}+\frac{O Z_{n+1}}{i-g} \cdot \frac{1}{(1+i)^{n}},
$$

for a continuing value, the following relationship applies $(i>g)$

where:

$O Z_{t} \quad$ - withdrawable resources during the evaluated period $[€]$,

$i \quad-$ the rate of capitalization in percent, which is used in a decimal form [\%/100],

$O Z_{n+1}$ - the volume of withdrawable resources in the year following the monitored period [ $\left.€\right]$,

$g \quad-$ the sustainable rate of growth of withdrawable resources in percent, which is used in a decimal form $[\% / 100]$,

$n \quad-$ the length of the observed period [year].

The continuing value (HP) is the value of the company's withdrawable resources in the year following the observed period, taking into account the company's prerequisites to generate withdrawable resources over an unlimited period that is recalculated to the present value on the valuation date.

The sustainable growth of withdrawable resources $(\mathrm{g})$ represents a percentage change in the annual capacity of a company to generate withdrawable resources. It depends on the company's condition on the valuation date and its development during the evaluated period within its industry, in the context of its history.

The sustainable growth rate in the expert testimony is determined in accordance with established practices, such as the Gordon model, geometric series and arithmetic series. The selected methodological procedure in the expert testimony must be specified.

The capitalization rate (i) is determined as follows:

$$
\begin{gathered}
i=(1-D S) \cdot N_{P K} \cdot \frac{P K}{C K}+N_{V K} \cdot \frac{V K}{C K} \\
C K=P K+V K[€],
\end{gathered}
$$

Where

$i \quad-$ the calculated rate of capitalization in percent reflecting the level of risk, the average cost of capital and the structure of the capital employed, which is used in a decimal form [\% / 100], 
$D S$ - the rate of income tax in percent, which is determined by the Income Tax Act for the valuated company, in the calculation it is used in a decimal form [\% / 100],

$N_{P K}$ - the cost associated with using the borrowed capital in percent, i.e. interest and other costs paid by creditors. They are used in a decimal form [\% / 100],

$P K$ - the volume of borrowed capital. It consists of the components of liabilities that are used to calculate the capitalization rate, namely long-term bank loans, current bank loans, financial assistance, $N_{V K}$ - the cost of own capital in percent, i.e., the share of the profit expected and earned by the owner for the investment of their capital in the company, which is used in a decimal form [\% / 100],

$V K$ - the volume of own capital that consists of the components of liabilities. For the purpose of calculation, these components are the equity $[€]$.

$C K$ - total capital, which is the sum of own and borrowed capital $[€]$.

The yield method is applied when determining the value of a transport company or its part, for example, when an entrepreneur needs to know the value of a company for sale, or when the business partners need to know the value of a business share in case they want to settle financial issues. The advantage of this method is that it takes into account the yield potential of the company and is less demanding compared to the asset method. It does not require such a team of experts as the asset method. An entrepreneur receives information about the value of the company as a whole but does not know the value of the individual assets and liabilities. It cannot be used, for example, if a newly established company needs to book an asset.

In the yield method, the expert relies on the financial plan of the transport company (ideally for the next 5 years), which is submitted by the contractor. The expert must examine the feasibility of the business plan, e.g. outlined by the financial-economic analysis of past development.

After the phase of the method selection, the implementation phase takes place, where the method should be correctly applied in the company. If the method is not used correctly, or it does not take into account all the crucial factors, it can have a significant impact on the company's final value. As this issue is extensive, we will only demonstrate some examples of applying wrong or incomplete information.

\section{Influence of coefficients and variables on the final value of the transport company}

Asset method

In the asset method, experts work with various information such as bookkeeping records, contracts, installment schedules, asset cards, etc. The basic values of asset components are modified using different coefficients. These coefficients must include all factors that affect the value of a particular component. This process is called the objectification process. Most companies record receivables, as well as liabilities in their books, so it is most convenient to use these asset items as an example.

In the case of receivables, we will specify the customer, namely AZ, ltd. The evaluated company records an unpaid invoice of EUR 15,000 against AZ, ltd., where the due date was November 5, 2017. The value of the company as a whole is determined as of December 31,2017. No more information in terms of the invoice was submitted, the customer appears to be active. In case the receivable is included in the group of active customers, the resulting total value of this asset component is recalculated by the enforcement coefficient $\mathrm{kv}=0.8$. It follows that the general value of the receivable is $15000 * 0.8=12000$ Euros.

This is based on the information from the expert testimony contractor. However, the expert found that AZ, ltd. is in bankruptcy, highly indebted, and does not communicate with the evaluated company at all. For this reason, it is necessary to consider that customer as risky and inactive and include it in the bankruptcy group. As the evaluation is carried out with a time delay, the expert knows that the company in question is inactive not only as of December 31, 2017, but also in 2018 when the expert testimony is being prepared. Due to this, a minimum coefficient of enforcement $\mathrm{kv}=0.01$ was assigned here. Then the general value of the receivable is $15000 * 0.01=150$ Euros. If the group of evaluated items includes more inactive customers on whom incorrect information has been provided, it can have a significant impact on the resulting overall value of the company. It is also necessary to consider the purpose for which the company is valued.

The second example is related to trade liabilities, where supplier $\mathrm{ABC}$, ltd. is also the customer of the evaluated company. The recorded receivables include an invoice amounting to EUR 30,000 which is three years overdue, as the due date was of December 31, 2017. The liabilities include a supplier's 
invoice from this company, in the amount of 18,000, two months overdue. If the receivable of EUR 30,000 was evaluated separately, considering the facts that it was overdue and included in the active customer group, the receivable would be recalculated by the coefficient of enforcement $\mathrm{kv}=0.2$. The general value of this receivable would be $30000 * 0.2=6000$ Euros.

However, this is a misconception, because we cannot separate the receivables and liabilities of the same company since they can be offset against each other. It follows that the value of the receivable may be reduced to a maximum of the liability.

The value of the company's assets cannot include an asset that is not settled: stated: "The subject of the valuation of the overall value of the company is all settled assets. Unsettled assets do not form a part of the company's general value until the date of completion of the expert testimony." (Sedlakova, 2012)

This example demonstrates that the inclusion of an asset in the incorrect group and the assignment of an incorrect coefficient leads to a distortion of the resulting general value. Therefore, collecting information and supporting documents is one of the basic steps in the company's valuation.

Yield method

In the yield method, it is necessary to take into account the specificities arising from the functioning of the company and the model of the yield method itself. A weakness of this method is the unlimited life of a company: "We live at a time when the estimated unlimited life of companies is becoming increasingly fictional. Everyday experience shows us that company insolvency is, on the contrary, a common issue. The possibility of insolvency should also be reflected in the valuation. The value of a stable company should be greater than that of companies that are unstable." (Mařik, 2014) As a possible solution here he suggested to estimate the life of the company. However, this is very difficult in practice. Therefore, foreign theory and practice keep on considering an unlimited lifetime.

Identifying value by a yield method with unlimited lifetime is a demanding process, especially in terms of correct input of parameters in the calculation. From the perspective of the whole model of the yield method, there is obviously a high sensitivity to any change of variables in the formula, so the expert must be very cautious about the calculation. In this paper, we demonstrate how the model responds to a change in the capitalization rate - $\mathrm{i}$ and the sustainable rate of growth - $\mathrm{g}$.

If $i=0.1160$ (in \%/100) and $g=0.013$ (in \%/100)

\begin{tabular}{|c|c|c|c|c|c|c|c|}
\hline $\begin{array}{l}\text { Company plan linked to } \\
\text { past developments }\end{array}$ & 2015 & 2016 & 2017 & 2018 & 2019 & 2020 & OZn+1 \\
\hline $\begin{array}{l}\text { Withdrawable resources } \\
(\mathrm{OZ})\end{array}$ & 6668 & 6754 & 6842 & 6931 & 7021 & 7112 & 7205 \\
\hline $1 /(1+\mathrm{i})^{\wedge} \mathrm{t}$ & 0.89606 & 0.80292 & 0.71946 & 0.64468 & 0.57767 & 0.51762 & 0.51762 \\
\hline $\operatorname{Hoz}(\mathrm{t})$ & 5974 & 5423 & 4923 & 4468 & 4056 & 3682 & 3729 \\
\hline
\end{tabular}

Source: Author

Value of the withdrawable resource $\mathrm{Hoz}=28$ 525.613Eur

Continuing value $\quad \mathrm{H}_{\mathrm{P}}=36$ 207.397Eur

General value of the company $\quad \mathrm{VSH}_{\mathrm{P}}=\mathrm{Hoz}+\mathrm{Hp}=64733.010$ Eur

If $\mathrm{i}=\mathbf{0 . 0 5}$ (in \%/100) and $\mathrm{g}=\mathbf{0 . 0 1}$ (in \%/100)

Table 2. Yield method If $\mathrm{i}=0.05$ (in \%/100) and $\mathrm{g}=0.01$ (in \%/100)

\begin{tabular}{|l|c|c|c|c|c|c|c|}
\hline $\begin{array}{l}\text { Company plan linked to } \\
\text { past developments }\end{array}$ & $\mathbf{2 0 1 5}$ & $\mathbf{2 0 1 6}$ & $\mathbf{2 0 1 7}$ & $\mathbf{2 0 1 8}$ & $\mathbf{2 0 1 9}$ & $\mathbf{2 0 2 0}$ & OZn+1 \\
\hline $\begin{array}{l}\text { Withdrawable resources } \\
(\mathbf{O Z})\end{array}$ & $\mathbf{6 6 6 8}$ & $\mathbf{6 7 3 4}$ & $\mathbf{6 ~ 8 0 2}$ & $\mathbf{6 ~ 8 7 0}$ & $\mathbf{6 ~ 9 3 8}$ & $\mathbf{7 ~ 0 0 8}$ & $\mathbf{7 0 7 8}$ \\
\hline $1 /(1+\mathrm{i})^{\wedge} \mathrm{t}$ & 0.89610 & 0.80299 & 0.71956 & 0.64479 & 0.57780 & 0.51776 & 0.51776 \\
\hline $\mathrm{Hoz}(\mathrm{t})$ & 5975 & 5407 & 4894 & 4429 & 4009 & 3628 & 3665 \\
\hline
\end{tabular}

Source: Author 


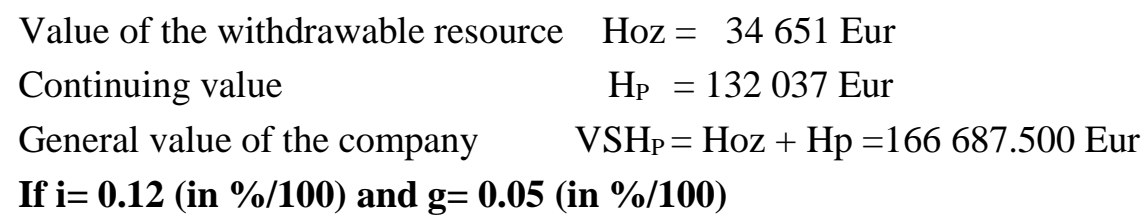

Table 3. Yield method If $\mathrm{i}=\mathbf{0 . 1 2}($ in $\% / 100)$ and $\mathrm{g}=\mathbf{0 . 0 5}$ (in \%/100)

\begin{tabular}{|l|c|c|c|c|c|c|c|}
\hline $\begin{array}{l}\text { Company plan linked to } \\
\text { past developments }\end{array}$ & $\mathbf{2 0 1 5}$ & $\mathbf{2 0 1 6}$ & $\mathbf{2 0 1 7}$ & $\mathbf{2 0 1 8}$ & $\mathbf{2 0 1 9}$ & $\mathbf{2 0 2 0}$ & $\mathbf{O Z n + 1}$ \\
\hline $\begin{array}{l}\text { Withdrawable resources } \\
(\mathbf{O Z})\end{array}$ & $\mathbf{6 ~ 6 6 8}$ & $\mathbf{7 ~ 0 0 1}$ & $\mathbf{7 ~ 3 5 1}$ & $\mathbf{7 ~ 7 1 8}$ & $\mathbf{8 ~ 1 0 4}$ & $\mathbf{8 5 1 0}$ & $\mathbf{8 9 3 5}$ \\
\hline $1 /(1+\mathrm{i})^{\wedge} \mathrm{t}$ & 0.89286 & 0.79719 & 0.71178 & 0.63552 & 0.56743 & 0.50663 & 0.50663 \\
\hline Hoz $(\mathrm{t})$ & 5953 & 5581 & 5232 & 4905 & 4599 & 4311 & 4527 \\
\hline
\end{tabular}

Source: Author

Value of the withdrawable resource $\mathrm{Hoz}=30$ 581.522 Eur

Continuing value

$$
\mathrm{H}_{\mathrm{P}}=64668.478 \text { Eur }
$$

General value of the company $\quad \mathrm{VSH}_{\mathrm{P}}=\mathrm{Hoz}+\mathrm{Hp}=95250.000$ Eur

The stated calculations indicate that the most significant effect on the final company value by the yield method with an unlimited lifetime has a continuous value, which is very sensitive to the relationship between the rate of capitalization and $\mathrm{g}$ - the sustainable growth rate.

\section{Conclusion}

Based on the above calculations, it is necessary to consider the condition of the company in terms of its life cycle stage. The asset method needs to obtain the necessary information to avoid any distortion of the resulting value and to ensure that coefficients consider all the specifics of the company's assets.

The yield method features a large number of variables that affect the resulting value. The paper shows the impact of the change in the rate of capitalization and $\mathrm{g}$ - the sustainable growth rate and the significant impact of the continuing value on the general value of the company. In this case, it might be necessary to consider adjusting the calculation methodology for risky companies. It is worth considering whether it is less risky to estimate the company's residual life and not to consider it permanent. The difficulty of estimating the remaining life span of a company is one of the main reasons why foreign practices and theories insist on an unlimited life span. For operating companies, this error will not be great. However, this will have a different impact for weaker enterprises. The estimate of the actual life of a company is associated with a smaller error in the value of the transport company than when an unlimited life is applied.

\section{Acknowledgment}

Supported by VEGA 1/0152/18 Business models and platforms in digital space.

\section{References}

Act of the Slovak Republic no. 382/2004 Coll. on experts, interpreters and translators, as amended.

Decree of the Ministry of Justice of the Slovak Republic no. 492/2004 Coll. on the determination of the general value of assets, as amended.

Dong, YQ, 2018, Enterprise Value Evaluation Based on FCFF Model - A Case Analysis of Beixinyuan Company, Book Series: Advances in Social Science Education and Humanities Research, Pages: 615-620, ISBN: 978-94-6252-476-7, https://doi.org/10.2991/emehss-18.2018.124

Dong, X., Qi, JP., 2018, Study on EVA Evaluation and Enterprise Over-Investment Behavior, 5TH International Conference on Business, Economics and Management (BUSEM 2018) Pages: 33-38, ISBN: 978-1-912407-05-7, https://webofproceedings.org/proceedings_series/article/artId/2317.html\#location, DOI: 10.25236/busem.2018.007

Gu, WT., Zhou, SM.; Dong, Z.,2017, Does CEP Influence Corporate Value? Evidence from Chinese Manufacturing Enterprise, Journal of advanced computational intelligence and intelligent informatic Pages: 1102-1110 https://www.fujipress.jp/jaciii/jc/jacii002100061102/ ; DOI 10.20965/jaciii.2017.p1102

Huang, HP., Huang, HM., 2017, Research on Evaluation Method of Intangible Assets, Book Series: DEStech Transactions on Social Science Education and Human Science Pages: 17-21, ISBN: 978-1-60595-517-9 http://www.dpiproceedings.com/index.php/dtssehs/article/view/19170/18664 ; DOI 10.12783/dtssehs/icssd2017/19170

Jankalova, M. (2013) Conceptions Based on Definition of Business Factors of Successfulness for the Support of Reaching the Excellence of Enterprise Subjects.In: Conference: 1st World Congress on Administrative and Political Sciences 
(ADPOL) Location: Antalya, TURKEY Date: NOV 28-DEC 01, 2012, WORLD CONGRESS ON ADMINISTRATIVE

AND POLITICAL SCIENCES Book Series: Procedia Social and Behavioral Sciences Volume: 81 Pages: 531-535

Published: 2013, https://doi.org/10.1016/j.sbspro.2013.06.472

Kislingerova, E., 2001 Company valuation, C.H.Beck Praha ISBN 80-7179-529-1

Majduchová, H., Rybárová, D., Grančičová, K., Križan, M., 2018, Business Economy, Wolters Kluwer SR s.r.o., ISBN 978 80-8168-806-5

Mařík,M., Maříková, P., Buus, T., Rýdlová, B.,2018, Business valuation methods for advanced, Ekopress, s.r.o. ISBN 978 80-87865-42-2

Mařík,M., 2014, Towards a fiction of infinite firms lifetime, Proceedings of expert activity and perspectives of its further development ISBN 978-80-225-3928-9, Bratislava Pages 8-15

Na, W., Qian, R., 2017, Enterprise Value Evaluation: Application and Improvement based on Cash Flow Model and Economic Value Added Model, Book Series: Advances in Social Science Education and Humanities Pages: 185-190, https://doi.org/10.2991/hsmet-17.2017.38

Sedláková, I. Žilina 2012, The Intersection of Expert Fields in Application of Enterprise Asset Valuation Principle, Proceedings of expert appraisals in the process of expert appraisal ISBN 978-80-554-0501-8, Pages 35-43

Stofkova, K., Stofkova, J. (2010) Implementationn of the Knowledge Management as a Competitive Advantage. In: Conference: 2nd Int. Conf. On Education and New Learning Technolgies EDULEARN Location: Barcelona, Spain Date: JUL 05-07, 2010 Book series: EDULEARN Proceedings Pages: 1323-1328 Published: 2010 